\title{
A census of marsh deer in Iberá Natural Reserve, its Argentine stronghold
}

\author{
Marcelo D. Beccaceci
}

The marsh deer Blastocerus dichotomus is one of the largest mammals in South America. It is classified as vulnerable by IUCN (1990) and is listed on Appendix I to the Convention on International Trade in Endangered Species of Wild Flora and Fauna (CITES). Very little field-work has been done to ascertain its status and current distribution and the survey described here is the first attempt to census the marsh deer numbers in the Iberá Natural Reserve, the Argentine stronghold of the species. The survey found only 1100 individuals with a smaller percentage of yearlings than would be expected in a healthy population. Hunting, competition with domestic stock for grazing and transmission of diseases from cattle may be combining to limit population growth and further research is needed to form the basis of a mangement plan for the species.

The marsh deer occurs only in or near marshy habitat in Argentina, Brazil, Bolivia, Paraguay and Peru. Total numbers are unknown but it is certainly declining in all areas as a result of poaching, diseases transmitted by domestic stock and habitat loss to cattle ranching and agriculture. The largest known population of this species is in the Pantanal of the Brazilian Mato Grosso and was reported to number as many as 7000 animals in 1978, but with the population probably declining (Schaller and Vasconcelos, 1978). The Iberá Natural Reserve in Argentina is the other major stronghold of this species.

This paper reports the results of an extensive survey that estimated the total number of marsh deer in the reserve and identified areas of highest deer density. It also provided essential information about population structure.

\section{Iberá Natural Reserve}

The esteros (marshes in Spanish) of Iberá are located in north-east Argentina, in the central and north-eastern part of Corrientes Province (Figure 1). They comprise a vast basin of inundated grassland, swamps, lagoons and floating islands of massed vegetation. The name
Iberá comes from the Guaraní language ( ${ }^{\prime} \mathrm{\prime}$ ' water, 'berá' $=$ glitter). The provincial reserve was established in 1983 and has a total area of $12,000 \mathrm{sq} \mathrm{km}$ covering about 15 per cent of the province.

The central part of Iberá consists of swamps and shallow lagoons less than $5 \mathrm{~m}$ deep surrounded by higher land. There are seven lakes with areas greater than $14 \mathrm{sq} \mathrm{km}$. Most of the basin is at least periodically flooded. The esteros are rain-fed and the water drains through the Miriñay River into the Uruguay River and into the Paraná River through the Corriente River.

The Ibera is the second largest wetland in South America, smaller only than the Pantanal of Brazil. Situated between $50-80 \mathrm{~m}$ above sea level, the climate is hot with summer temperatures (December to March) reaching a maximum of $44^{\circ} \mathrm{C}$, while the mean in winter (June to September) is $16^{\circ} \mathrm{C}$. Yearly rainfall is about $1400 \mathrm{~mm}$.

\section{Vegetation of Iberá}

Three botanical provinces overlap or converge in Iberá: Eastern Subtropic, Chaqueña and Espinal. Aquatic vegetation includes extensive 


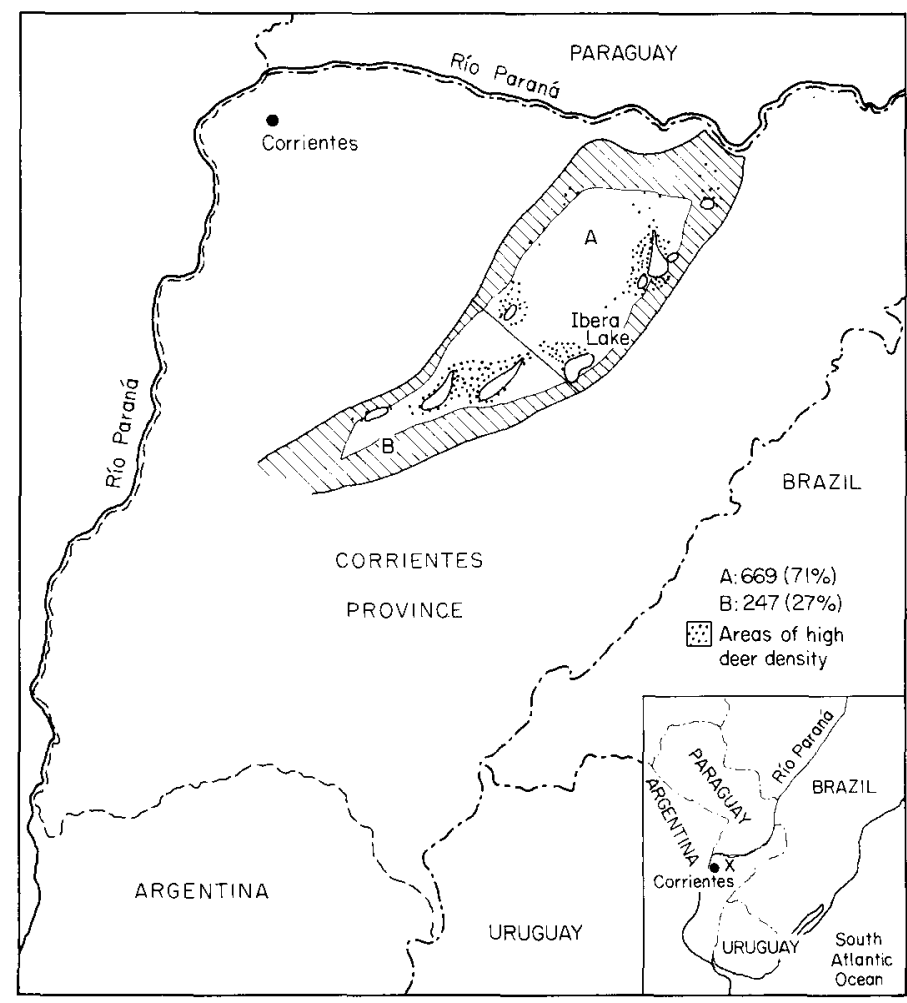

Figure 1. Iberá Natural Reserve, Corrientes Province, Argentina, showing distribution and density of marsh deer. On the inset map $\times$ marks the location of Iberá Natural Reserve. areas of Cabomba australis, Egeria naias, Scirpus californicus and Eichornia spp. among others. The lakes are edged by strips of floating vegetation, which in places form floating islands of rotted roots and soil (embalsados). These can be up to several hundred metres wide. The dominant species among the 20-30 that form these islands include Cyperus giganteus, Panicum spp. Typha spp. and Thalia multiflora. In places this formation is sufficiently thick and solid to support trees and the weight of animals as large as the marsh deer. On the higher ground and around the marshes, strips of subtropical and patches of mixed woodland can be found. The terrestrial vertebrates include 85 species of mammals, 360 species of birds, 35 reptiles and almost 40 amphibians. There are several endangered species in the Red List of the IUCN (1990), such as the maned wolf Chrysocyon brachyurus, La Plata otter Lutra longicaudis and the broad-nosed caiman Caiman latirostris.

This reserve stands out because it encom- passes an entire ecosystem: the watershed of the Corriente River. The boundaries of the reserve are essentially the boundaries of the Iberá watershed, with most of the permanently dry land around the perimeter of the reserve under private ownership, primarily by cattle ranchers (Figure 1.

\section{Habitat of the marsh deer in Iberá}

Only parts of Iberá represent good deer habitat and almost all the individuals are concentrated close to or on the edge of permanent water bodies - lakes, lagoons, rivers and streams - where the water is not too deep, preferably not more than $0.6-0.7 \mathrm{~m}$, with a fringe of low vegetation, such as cattails or reeds. Between these areas, the water level is too high and the swamps are too deeply flooded for deer. 


\section{Iberá deer census}

The marsh deer's russet coat and preference for open habitat make it highly conspicuous from above, and thus it is one of the few south American mammals that can be counted from a plane (Schaller and Vasconcelos, 1978). Areas of suitable deer habitat noted on survey flights were selected for the census, the intensity of coverage depending on deer numbers (Schaller and Vasconcelos, 1978).

Our aerial transects consisted of flying along selected lines following the courses of the rivers and streams and the shores of the lakes and lagoons. The length of the reserve is $250 \mathrm{~km}$ from south-west to north-east and it varies in width from $88 \mathrm{~km}$ in the north, 174 $\mathrm{km}$ in the middle and $20 \mathrm{~km}$ in the south. By this method, 90 per cent of the reserve was covered, virtually all significant deer habitat (Figure 1).

Deer distribution was plotted in April and October 1991 during 11 flight hours and the areas was censused during 16 hours in June 1992. Four observers, including the pilot, counted all animals along parallel strips $2 \mathrm{~km}$ apart flying at an altitude of $70 \mathrm{~m}$. The reserve was divided into two areas (north, $\mathrm{A}$, and south, B) using Iberá Lake as a reference. The flight pattern was generally north-south. We counted 916 deer unevenly distributed and concentrated by permanent lakes with marshy borders, with 669 in part A and 247 in B (Figure 1). The calculated total for the whole area is $1000-1100$ individuals.

We tried to age and sex each deer, although some animals had to remain unclassified because they were not completely visible or were seen only briefly (Table 1). The birth

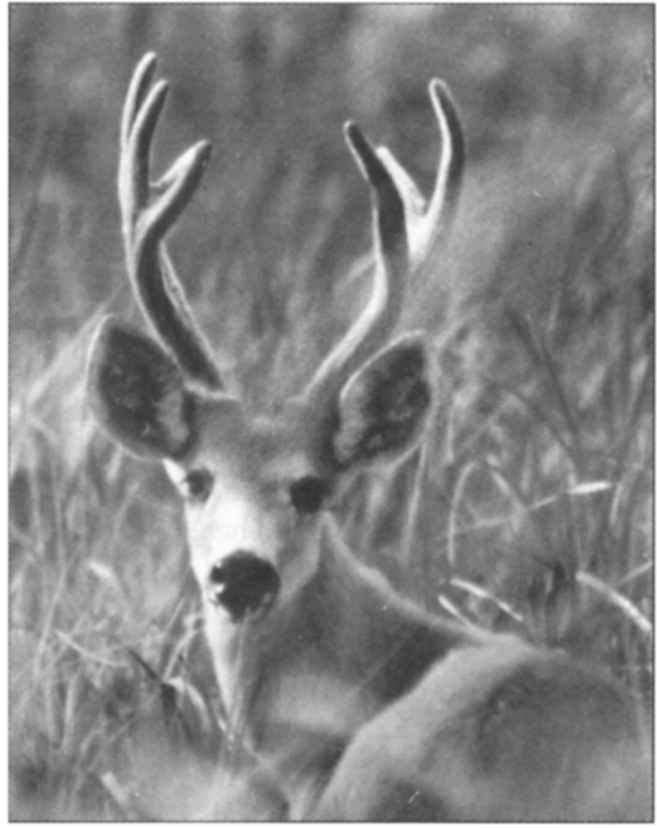

Marsh deer in Iberá Natural Reserve, Argentina (M. D. Beccaceci).

season extends over at least 6 months, from May to October, and, as the census was made in late June, few fawns were seen. Of the total number of adults identified, 34 per cent were males and 66 per cent females. According to Schaller and Vasconcelos (1978), yearlings should comprise at least 20 per cent to compensate a normal deer population for its average adult mortality. This census revealed only 6 per cent yearlings, males and females combined (see Table 1).

During the census we tallied five deer that had just died, apparently of disease. We also

Table 1. Composition of the marsh deer population in Iberá Natural Reserve

\begin{tabular}{|c|c|c|c|c|c|c|}
\hline \multirow[b]{2}{*}{ Date } & \multirow[b]{2}{*}{ Area } & \multicolumn{5}{|c|}{ No. individuals } \\
\hline & & $\begin{array}{l}\text { Adult } \\
\text { male }\end{array}$ & $\begin{array}{l}\text { Adult } \\
\text { female }\end{array}$ & $\begin{array}{l}\text { Adult } \\
\text { unidentified }\end{array}$ & $\begin{array}{l}\text { Yearling } \\
\text { combined }\end{array}$ & Fawn \\
\hline $26 \& 27$ June 1992 & A & 163 & 289 & 185 & 28 & 4 \\
\hline $27 \& 28$ June 1992 & $\mathrm{~B}$ & 36 & 97 & 84 & 27 & 3 \\
\hline Total & & 199 & 386 & 269 & 55 & 7 \\
\hline Percentage & & 21.7 & 42.1 & 29.3 & 6 & 0.7 \\
\hline
\end{tabular}


explored the swamps on foot and found several carcasses, many of them young males. It is known that foot-and-mouth disease, brucellosis and probably the bood-parasite Babesia are prevalent in local cattle. A necropsy of one animal found dead found signs of low levels of calcium in the large bones and the presence of Paramphistomum, a parasite that affects normal calcium metabolism. This deer was also heavily infested with ticks Boophicus microplus.

Deer tolerate endoparasites to some degree but overstocking, poor nutrition and absence of shelter in bad weather can make the deer more susceptible and their health suffers inconsequence.

\section{Conservation of the marsh deer at lberá Reserve}

This survey is significant for several reasons. It is the first time a marsh deer census has been made in the Argentina stronghold of the species. It is also the first time nearly the entire $1,200,000$ ha of the reserve have been covered by air. The survey has provided not only the total number and concentrations of this endangered deer but has enabled identification of target areas for preservation. Some poaching was evident during aerial observation. The poachers' points of entry were located, which will assist the rangers in patrolling the area more effectively.

The fact that only 1100 individuals are living in an area of $1,200,000$ ha cannot be explained as due to lack of suitable habitat. The animals are confined to isolated patches of shallow marsh and scarce high ground in the interior of the reserve, which is predominantly government-owned. The entire perimeter of the reserve would also be potentially usable, and would perhaps be preferable because it is not flooded so frequently. The land, however, is monopolized by cattle in this largely privately-owned reserve. In addition to being susceptible to diseases transmitted by domestic stock, the deer are easily hunted in this accessible area.

Inspection of Table 1 shows that the subadult segment of the population is prob- ably declining, because there is a low percentage of yearlings. As this study proved, the deer are susceptible to a number of diseases. Further research will need to be carried out to establish if there is a relationship between disease and the small number of yearlings. In addition, information on habitat quality, quantity and successional state is needed in order to interpret population status. Ultimately we need to identify the factors that are limiting population increase, and to develop practicable plans to alleviate their effects, allowing the population to increase to secure status. The first steps in this direction have been taken with this survey and further in-depth study will provide the basis for a comprehensive management plan.

\section{Acknowledgments}

I wish to express my gratitude to The Nature Conservancy, Missouri Chapter, for its timely support of this field study. I extend my warmest thanks to Jan Armstrong for her perseverance and support. I also acknowledge Alfredo Lichter of Isaura for his company's early contribution of funds, which resulted in the proposal for this project.

During the aerial surveys I was helped by the pilot Quique Friedrich, Dr Vicente Fraga, Marcos Garcia Rams, and José Gauto. I also thank Dr Pedro Perea Muñoz, Director of the Iberá Natural Reserve, for his assistance and rangers Molina, Piedrabuena and Rodríguez. The skills of ranger Cabrera were particularly important during the exploration of the marshes.

Dra. Mas performed some of the laboratory analyses for the identification of endoparasites.

Bonnie J. Hayskar read later drafts of the manuscript and made suggestions for its improvement.

\section{References}

IUCN, 1990. 1990 IUCN Red List of Threatened Animals. IUCN, Gland, Switzerland and Cambridge, UK.

Schaller, G.B. and Vasconcelos, J.M.C. 1978. A marsh deer census in Brazil. Oryx, 14 (4), 345-351.

Marcelo D. Beccaceci, Boedo 90 - Florida (1602), Buenos Aires, Argentina. 